\title{
Alienation Effect in Churchill's Mad Forest: A Brechtian Analysis
}

\section{Churchill'in Deli Ormanı'nda Yabancılaştırma Etkisi: Brechtyen Analiz}

\begin{abstract}
Serkan ERTIN*
Abstract: Bertolt Brecht's epic theory consists of formal and ideological elements. These two elements are indivisible because Epic Theatre represents the changing social and political circumstances with the help of changing dramatic conventions. Both formal and ideological elements are used in Brecht's Alienation Effect to minimize the emotional involvement of the audience. Brecht demanded the audience be intellectually involved with the play so as to receive the social and political messages in the play. Bertolt Brecht was not the first to use the Epic tradition, and to be sure he was not the last. Caryl Churchill, one of the most successful woman playwrights in Britain, is one of the practitioners of Epic Theatre. Churchill is mostly known for her feminist plays, but in her plays -just like Brecht's- she combines her ideological commitment with theatrical experimentation. In 1990, only months after Ceauşescu had been deposed, Churchill visited Romania with some students from a London theatre school. Their experiences there resulted in her play, Mad Forest. This paper will be an analysis of Churchill's use of the Alienation Effect through Epic conventions in her Mad Forest. Churchill, to avoid the emotional involvement of the audience and to make them aware of the theatricality of what they see, creates the Alienation Effect through her use of setting, plot structure, characterization, and theatrical instruments.
\end{abstract}

Keywords: Alienation Effect, Epic Theatre, Caryl Churchill, Bertolt Brecht

Öz: Bertolt Brecht'in epik kuramı biçimsel ve ideolojik elementlerden meydana gelmektedir. Bu ikisi birbirinden ayrılamaz çünkü epik tiyatro değişen siyasi ve toplumsal koşulları değişen drama gelenekleriyle temsil etmektedir. Hem biçimsel hem ideolojik elementler izleyicinin oyuna duygusal katılımını en aza indirgemek amacıyla Brecht'in yabancılaştırma etkisiyle birlikte kullanılır. Brecht tiyatro izleyicisinin oyuna siyasi ve toplumsal mesajları alabilmesi için yalnızca düşünsel katılımını hedefler. Epik tiyatro geleneğinde Brecht ne ilktir ne de son. İngiltere'nin en iyi kadın oyun yazarlarından Caryl Churchill de epik tiyatronun uygulayıcılarından biridir. Churchill esasen feminist oyunlarıyla bilinir, ancak Brecht gibi o da oyunlarında ideolojik bağlılıklarını teatral deneyselciliğiyle birleştirir. Yazar, 1990'da Çavuşesku'nun görevden alınmasından sadece aylar sonra Londra'da bir tiyatro okulundan öğrencilerle Romanya'yı ziyaret eder. Oradaki deneyimleri Deli Orman oyunuyla neticelenir. Bu makale Churchill'in epik gelenekler vesilesiyle Brecht'in yabancılaştırma etkisini Deli Orman oyununda nasıl yarattığını irdelemektedir. İzleyicilerin oyuna duygusal katılımı yerine gördüklerinin kurgusallığının farkında olmalarını isteyen Churchill, kullandığı olay yeri, olay örgüsü, kişi tasvirleri ve teatral araçlarla yabancılaştırma etkisi yaratır.

Anahtar Sözcükler: Yabancılaştırma Etkisi, Epik Tiyatro, Caryl Churchill, Bertolt Brecht

\footnotetext{
${ }^{*}$ Yrd. Doç. Dr., Kocaeli Üniversitesi Fen-Edebiyat Fakültesi, İngiliz Dili ve Edebiyatı Bölümü. Kocaeli. ertins@gmail.com]
} 


\section{Introduction}

The years between 1915 and 1945, covering two world wars, were characterised by unrest in the western world. Political and economic unrest gave way to the rise of totalitarianism in Europe. In the interwar years there were fascist dictatorships in Italy and Germany, nationalist dictatorships in several other countries, and a communist totalitarian dictatorship in the Soviet Union. The artists of the period reacted against both the chaotic state of the world and the traditional commercial theatre. Among these reactions some movements such as Futurism supported fascism, whereas some others like Epic Theatre supported socialism.

The standpoint underlying Epic Theatre is Marxist, which sees the world in constant process of change. Change is fundamental for the Marxist world-view. Changes are dialectical, that is, change results from conflicts and struggles, and they occur not in a line, but in curves, leaps or in explosive ways (Ewen 209). For Bertolt Brecht the only way to reflect this new view of the world in process of change was Epic Theatre, so he established the conventions of Epic Theatre from the late 1920's.

Bertolt Brecht's epic theory consists of both formal and ideological elements. These two elements are indivisible because Epic Theatre gives the changing social and political circumstances with the help of changing the dramatic conventions. Both formal and ideological elements are used with Brecht's Alienation Effect to minimise the emotional involvement of the audience. Brecht demanded the audience be intellectually involved with the play so as to gain the social and political messages in the play. Subiotto (206) likens this detached state of the audience in Epic Theatre to "the historian's critical view of events: he re-enacts them through description and indicates their relevance and significance through comment".

Bertolt Brecht was not the first to use the Epic tradition, and to be sure he was not the last. However, many practitioners of Epic Theatre followed his style. Caryl Churchill, one of the most successful woman playwrights in Britain, is one of the practitioners of Epic Theatre. Churchill is mostly known for her feminist plays, but in her plays -just like Brecht- she combines her ideological commitment with theatrical experimentation.

In 1990, only months after Ceauşescu had been deposed, Churchill visited Romania with some students from a London theatre school. Their experiences there resulted in her play, Mad Forest. This paper is an analysis of Churchill's use of the Alienation Effect through Epic conventions in her Mad Forest. Churchill, to avoid the emotional involvement of the audience and to make them aware of the theatricality of what they see, creates the Alienation Effect through her use of locale, plot structure, characterisation, and theatrical instruments.

\section{The Locale}

The setting of Epic Theatre is historical or in foreign lands because the aim is not to cause sensation. "An old story", says Benjamin, "will often be of more use to it than a new one" (Benjamin 16). Brecht's plays, therefore, are epic in scope, dealing with the history of foreign lands and shifting locale frequently. Churchill, accordingly, chooses Romania for the setting of her play Mad Forest, as seen in her introduction to the book:

On the plain where Bucharest now stands there used to be 'a large forest crossed by small muddy streams...It could only be crossed on foot and was impenetrable for the foreigner who did not know the paths... The horsemen of the steppe were compelled to go round it, and this difficulty, which irked them so, is shown by the name... Teleorman - Mad Forest.' (Churchill ix)

By giving this information at the very beginning of her play, Churchill distances the 
audience from the play. What the audience will see on the stage is nothing but a theatrical performance. Thus, the audience is emotionally detached from the dramatic action and they will not identify themselves with the characters on the stage.

Brecht's shifting locale is also employed by Churchill in Mad Forest. The play starts in the house of Vladu family. The conflict between Bogdan and his daughters is seen, though none of the characters speak in the scene (Churchill 13). However, the second scene, which comes shortly after the first one, takes place in the Antonescus' house, and this time another conflict between Radu and his parents appears (Churchill 14). The following scene is again in the residence of the Vladu family. Lucia and Florina are seen talking about Lucia's American husband Wayne and Radu, who will later turn out to be a former lover of Lucia (Churchill 15). Then, Flavia Antonescu meets the audience in the fourth scene and takes them to her class where she teaches her students about the President Nicolae Ceauşescu (Churchill 16). The fifth scene takes place outside and Radu is seen waiting in a queue of people with shopping bags (Churchill 17).

There is no end to this frequent shift of setting. Churchill presents the audience almost with a bombardment of slides. Using these interruptions, like Brecht, Churchill destroys the Aristotelian structure in terms of the unity of place. This is also a challenge to the theatre of the time as well, the theatre which is "dramatic, full of tensions and conflicts" (Gray 72). The ultimate aim in Epic Theatre is the Alienation Effect and it is achieved because the audience do not associate themselves with a single perspective given in a single setting. In this way the audience gets the social and political messages in the play more easily.

\section{Plot Construction}

Instead of interrelated scenes in a cause-effect relationship, like those in well-made plays and realistic drama, Brecht employed "a panoramic span of events" which does not form an organic unity from which one cannot omit any scene (Subiotto 197). Against the definitions on drama set in Aristotle's Poetics, Brecht creates his "non-Aristotelian" new poetics for a new world (Ewen 212). Each scene in Epic Theatre, thus, is itself an autonomous entity. Subiotto (201) argues that the addition rather than integration of scenes is characteristic of epic theatre.

In Mad Forest, similarly, there are numerous scenes following one another without any cause-effect relationship. Each scene is there for itself. As Churchill states in the very beginning "Each scene is announced by one of the company reading from a phrasebook, as if an English tourist, first in Romanian, then in English, and again in Romanian" (Churchill 13). The change of language used by the actors interrupts the linear flow of the play. This fact gives each scene a unique character and identity. For example, the seventh scene is announced as "Ascultati? Are you listening?" (Churchill 19). The title of the scene makes it independent of other scenes. Unlike in traditional drama, the omission of this scene, for instance, will not destroy the meaning of the play.

The fifteenth scene is titled as "Pe Irina o doare capul. Irina has a headache" (Churchill 15). The title also comments on the scene. Most scenes in the play, like this fifteenth one, have no action but only narrative. This brings the narrator to the foreground in Epic Theatre. In this fifteenth scene the stage direction reads: "Lucia is trying on her wedding dress, helped by Irina", and this forms all the scene (Churchill 28). The scenes are quite short in the play, they are not interrelated, and sometimes the characters do not utter even a single word.

Act III Scene I is titled "Ciinelui ii e foame. The dog is hungry" (Churchill 44). The dialogue in the scene is between a Dog and a Vampire. The Dog is looking for a new owner, for 
the former one threw him out. When he meets the Vampire, he wants to be his dog because he is in need of company and care. As soon as the Vampire bites the neck of the Dog to turn it into a vampire, the scene ends and the audience finds Gabriel, the son of the Vladu family, in a room in hospital (Churchill 47). The scene with the Dog and the Vampire disappears here and it has no relation to any other scene in the play.

Churchill's aim lying behind this sort of plot construction is to prevent the audience from identifying or sympathising with any of the characters. She creates the Alienation Effect through the use of successive scenes which are quite short, independent, intricate, interrupted and announced by the actors. In Epic Theatre the audience must always be kept awake and be reminded of the theatricality of the play, not to be "passive, hypnotised by the performance" (Gray 73).

\section{Characters}

The task of the actor in Epic Theatre is to narrate his story rather than to create the illusion of reality. Ewen sees the place of the actor "at a distance from the role he is portraying, as if looking at it, too". To clarify this distance he gives Brecht's famous example of a street accident reported by a bystander. The description of this witness, his narration of what happened and how it happened is of great importance for Brecht because it shows how the accident might have been avoided (Ewen 227). Like the witness, the actor should avoid empathy and identification in Epic Theatre. On the task of the actor, Jameson says that the actor is to show the character he is playing and its traits "without trying to become the role" (Jameson 39).

The characters, accordingly, do not sustain "the Ibsen-like illusion" that they really exist there unaware of the audience (Gray 70). In an Ibsen play the audience would see the events taking place inside of a room through the transparent fourth-wall. In this way they would identify themselves with the characters and become emotionally involved with the play. However, unlike Aristotle's notion, the aim of the Epic Theatre is not 'catharsis', that is, the arousal of pity and fear in the audience in order to cleanse them of these emotions. For Brecht, Ewen states, catharsis is bound up with the more modern term "empathy" (Ewen 214). In drama this is seen in the audience's identification with the actor or action on the stage. Epic Theatre is against any kind of empathy. The focus on the intervals is to destroy any such illusion. Therefore the Epic convention uses a large number of characters who act as if telling a story. The task of the actor is to narrate rather than to act.

In Churchill's Mad Forest there are thirty-nine characters named in the cast, excluding those people seen on the stage in queues and at the wedding as guests. In Act II the revolution is narrated by different members of the society, but there is no action on the stage. A Painter starts the story taking it from December 20, for instance, and a Girl Student carries it on from 21 December (Churchill 29). In the stage directions Churchill says each character talks as if others are not there (Churchill 29). For this reason each character's speech is interrupted by the story of another one. The story-telling is not linear, but different people complete the story:

Securitate. In the night the army cleaned the blood off the streets and painted the walls and put tar on the ground where there were stains from the blood so everything was clean.

Student 1. At six in the morning there is new tar on the road but I see blood and something that is a piece of skin. Someone puts down a white cloth on the blood and peoples throw money, flowers, candles, that is the beginning of the shrines (Churchill 35). 
The turmoil in the streets, the fight between the army and people, and the bloody events are narrated like a story told by the Securitate and Student 1 . They are not trying to create a mood and involve the audience. They are telling just what happened.

After the Securitate and Student 1, a Doctor, a Housepainter and then Student 2 speak, and they continue the story. For example, the Doctor says that "there were 14 dead and 19 wounded" and explains the different kinds of wounds, but the audience does not see any action on the stage. They listen to what the characters tell them, as if listening to a "narrative or storytelling" (Jameson 43). In this way the audience is distanced from the events.

Other tactics employed by Churchill to further alienate the audience are the use of unrealistic characters and grammatically incorrect English under the influence of Romanian. At the beginning of Act III a Vampire is seen talking to a Dog (Churchill 44). The use of these anti-realistic characters keeps the audience awake and shows them that what they are watching is a play. In Act III Scene VII Florina Vladu, a nurse, talks to the Ghost of the young man with whom all the nurses were once in love (Churchill 73). The use of the Ghost adds to the sense of fictionality in the play.

The language of the characters is full of grammatical mistakes. It is another element used by Churchill to create interruptions in the play. For example, Boy Student 1 says, when telling what happened, "I am a student and I watch the speech on TV. The TV went dead, I was sure at last something happens so I go out to see" (Churchill 30). The aim of incorrect grammar is to break the illusion of the play. A fluent language might affect and involve the audience, but these mistakes disturb the audience and keep them awake and aware of the message of the play. As a result of the Epic characterisation, instead of identifying themselves with the actors, "the audience is called upon to learn to be astonished at the circumstances within which he has his being" (Benjamin 18).

\section{Theatrical Instruments}

In Brecht's Epic Theatre all the theatrical instruments are made visible to the audience. Brecht does not want to hide preparations on the stage with the help of a curtain. For instance, the curtain can be "only half the usual height", and the stage, instead of being darkened, can be "lit up". On the curtain a sign can be flashed, "a motto, or a title, or a brief sentence telling the spectator what the play is about" (Ewen 225-6).

In this way Brecht ends the illusion on the stage and lets the audience see the theatricality of what they perform. The decor and props must also be carefully chosen. An elaborate decor might involve the audience with its life-like appearance. Thus, Epic Theatre uses decors and props and costumes as "mere indicators" (Ewen 226). For instance, to show that a scene takes place in a factory there is no need to find machinery or chimneys. Only a placard announcing wage-scales or a photograph of the proprietor would be adequate in Epic Theatre. Also documents, choruses, narrators, projections, films and music can be employed in order to estrange the action on the stage. Through these elements the audience must feel as if looking at footnotes or turning back the pages of a book. Brecht calls this effect the "literalization of the theatre" (Ewen 229).

Churchill, similar to Brecht, uses theatrical instruments in a different way from the traditional dramatic theatre. In Act I Scene XI a Soldier and a Waiter stand smoking in the street, and suddenly one of them shouts "Rat!", and they chase it (Churchill 25). However, in the "Production Note" to her Mad Forest Churchill says they did not use a prop rat. She admits that even the Vampire was not dressed as a vampire (Churchill viii). It exhibits the fact that 
Churchill does not want to create a realistic stage. She does not use elaborate or realistic props or decor. Even the costumes, as seen in the example of the Vampire, are not life-like. The audience must not take the characters for real, otherwise, they will fail to receive the social or political message of the play.

As for the use of music, like Brecht, Churchill makes extensive use of music throughout Mad Forest. In the very beginning while the company is reciting a poem praising Elena Ceauşescu, Romanian music stirs. The same music continues when the play starts in the Vladu's house, the music from the Vladu's radio (Churchill 13). At the end of the wedding ceremony of Lucia and Wayne there is a hymn, as Churchill (56) states in her "Production Note". Later, in Rodica's dream, and at the wedding party of Florina and Radu there is music in background (Churchill 5673). After the wedding, the old peasant Aunt shouts ritual chants at Florina (Churchill 76). At the end of the ceremony all the characters begin to dance listening to the lambada (Churchill 84).

Churchill uses music to support her theme in the play. She uses ritual chants at the wedding ceremony or the lambada for the celebration after the wedding. However, the main point in her use of music is that through this use of music she interrupts the linear movement of the play. John A. Price gives Churchill's use of music in her plays as an example for Helene Cixous' theory of "écriture feminine" [6 July 1999].

As a result of the use of music, unlike in the traditional theatre which captures the audience in its text, Churchill's Mad Forest gives the audience intervals to distance themselves from the play and to think about it. In this way Churchill, using theatrical instruments, avoids the emotional involvement of the audience and enables an intellectual one instead.

\section{Conclusion}

As Ewen (199) states, Bertolt Brecht regarded himself as an "experimenter", and his works as "efforts" or "experiments". He formed his Epic Theatre from a fusion of political and formal elements. He combined Marxism with various theatrical elements that constitute theatre; audience, performers, staging, and music. Especially the audience was the focus of his theory. He wanted to change the audience completely. He did not want them to get emotionally involved with the plays. He used all the formal changes to create the Alienation Effect he aimed at. Therefore, what Brecht introduced to drama was not a particular change of a single element, but a total one.

In Britain, Caryl Churchill followed the Epic convention of Brecht. In Mad Forest she creates the Alienation Effect through her use of setting, plot structure, characterisation, and theatrical instruments. She does not want to present a life-like performance on the stage. Her aim was to create interruptions so as to break up the realistic element of 'illusion' in the play. Only in this way can the audience be kept away from the mood of the play and concentrate instead on its social and political messages. 


\section{REFERENCES}

Benjamin W. (1983). Understanding Brecht. London 1983.

Churchill C. (1996). Mad Forest: A Play from Romania. New York 1996.

Ewen F. (1992). Bertolt Brecht: His Life, His Art and His Times. New York 1992.

Gray R. (1976). Brecht: The Dramatist. Cambridge 1976.

Jameson F. (1998). Brecht and Method. London 1998.

Price J. A. (1999) "The Language of Caryl Churchill: The Rhythms of Feminist Theory, Acting Theory, and Gender Politics". Original Articles. Retrieved from http://www.womenwriters.net/editorials/PriceEd1.htm

Subiotto A. (1989). "Epic Theatre: A Theatre for the Scientific Age". Ed. S. Mews, Critical Essays on Bertolt Brecht (1989). Boston. 